\title{
KOMPETENSI PROFESIONAL GURU GEOGRAFI DALAM PROSES PEMBELAJARAN MATERI LINGKUNGAN HIDUP DI KELAS XI SMA NEGERI 10 SINGKAWANG
}

\author{
Ihsan Nurhakim ${ }^{1}$, Ivan Veriansyah ${ }^{2}$ \\ ${ }^{1,2}$ Program Studi Pendidikan Geografi IKIP PGRI Pontianak \\ Jalan Ampera Nomor 88 Pontianak \\ 1e-mail: ihsannurhakim08@gmail.com
}

\begin{abstract}
Abstrak
Tujuan penelitian adalah untuk mengembangkan pembelajaran geografi melalui kompetensi profesional guru geografi dalam proses pembelajaran materi Lingkungan Hidup di Kelas XI Sekolah Menengah Atas Negeri 10 Singkawang. Penelitian merupakan penelitian kuantitatif berjenis deskriptif dan asosiatif yaitu menggunakan APKG 1 dan 2 sebagai alat ukur. Dari hasil penelitian APKG 1 memperoleh nilai 3,65 dengan karegori sangat baik dan APKG 2 memperoleh nilai 3,35 dengan kategori sangat baik. Sedangkan dari hasil angket 75,52 dengan kategori sangat baik. Berdasarkan hasil penelitian diketahui bahwa kompetensi profesional guru geografi dapat mengembangkan proses pembelajaran materi Lingkungan Hidup kelas XI SMA Negeri 10 Singkawang dengan kategori sangat baik.
\end{abstract}

Kata Kunci: kompetesi profesional guru, proses pembelajaran, lingkungan hidup.

\begin{abstract}
The purpose of this study was to develop geography learning through the profesional competence of geography teachers in the learning process of Environmental Materials at the eleventh grade students of SMAN 10 Singkawang. This research is a descriptive and associative quantitative research of APKG 1 and 2 as a measurement tool. The result of the research showed that: (1) APKG 1 score is 3.65 which was categorized as very good; (2) APKG 2 score is 3.35 which was categorized as very good; and (3) the finding also revealed thatquestionnaire score is 75.52 which was categorized as very good. As for the results of this study known that the profesional competence of geography teachers can develop the learning process of environmental material on the eleventh grade students of SMAN 10 Singkawang which was categorized as very good.
\end{abstract}

Keywords: teacher profesional competence, learning process, environment.

\section{PENDAHULUAN}

Abad ke-21 yang ditandai dengan globalisasi teknologi dan informasi, telah membawa dampak yang luar biasa bagi peran guru dalam proses pendidikan dan pembelajaran. Peran lama guru sebagai satu-satunya sumber informasi dan sumber belajar sudah tidak dapat dipertahankan lagi. Guru harus menemukan peran-peran baru yang lebih kontekstual dan relavan. Peran guru harus ditemukan 
karena bagaimanapun guru masih menjadi salah satu agen pembaharu dan penentu sejarah kehidupan umat manusia.

Guru sebagai komponen yang penting dalam proses pendidikan, memiliki peranan dan tugas yang sangat berpengaruh pada keberhasilan para penerus bangsa. Guru merupakan sumber utama untuk mengetahui atau mempelajari ilmu dan pengetahuan yang nantinya akan menjadi bekal para peserta didiknya dalam meneruskan kehidupan dirinya, keluarganya, maupun kehidupan bangsanya. Oleh karenanya, para guru hendaknya menjadi guru yang mempunyai kompetensi profesional dan berkualitas. Kompetensi profesional seorang guru akan sangat memengaruhi cara penyampaian atau mengajar seorang guru kepada para peserta didik, misalnya tentang pelestarian lingkungan hidup oleh guru geografi, yang bisa dilakukan secara optimal jika kompetensi profesional guru yang dimiliki diatas rata-rata.

Melalui peserta didik yang berkaitan langsung dalam proses pembelajaran di dalam kelas telah melakukan uji kompetensi guru berdasarkan pengukuran kompetensi profesional guru. Pada uji kompetensi guru terlihat hasil uji kompetensi guru geografi pada SMA Negeri 10 Singkawang, dari guru yang telah mengikuti uji kompetensi guru berdasarkan penilaian profesional yang telah dilakukan oleh peserta didik kelas XI terlihat guru 57\% mempunyai nilai $\leq 60$ dan $43 \%$ mempunyai nilai > 60. Maka dengan data tersebut, terlihat kemampuan kompetensi profesional guru geografi di SMA Negeri 10 Singkawang masih rendah.

Rendahnya kompetensi profesional guru di SMA Negeri 10 Kota Singkawang yang terlihat pada hasil uji kompetensi tentunya akan memengaruhi guru atau pendidik dalam menyampaikan materi, ilmu, dan pengetahuan yang akan disampaikan kepada siswa. Berdasarkan rendahnya kompetensi profesional para guru dalam penyampaian materi pelestarian lingkungan hidup tersebut dan sebagian besar guru masih memperoleh nilai profesional guru yang masih rendah, maka menarik untuk dilakukan penelitian tentang kompetensi profesional guru geografi dalam proses pembelajaran materi Lingkungan Hidup di Kelas XI Sekolah Menengah Atas Negeri 10 Singkawang. 


\section{METODE}

Metode yang digunakan dalam penelitian adalah metode deskriptif dengan pendekatan kuantitatif. Dengan menggunakan metode deskriptif diharapkan permasalahan dari penelitian yang dikemukakan dapat terjawab dengan analisis berdasarkan data yang terkumpul. Sasaran penelitian adalah SMA Negeri 10 Singkawang. Populasi dalam penelitian adalah siswa kelas XI IPS 1 dan XI IPS 2 pada SMA Negeri 10 Singkawang tahun ajaran 2018/2019, yaitu sebanyak 96 orang. Sampel yang digunakan dalam penelitian adalah siswa kelas XI IPS 1 dan kelas XI IPS 2 SMA Negeri 10 Singkawang yang berjumlah 60 orang, serta satu orang guru sebagai penilai teman sebaya. Teknik pengambilan sampel yaitu menggunakan non probability sampling, yaitu purposive sampling dengan kriteria siswa yang tidak tuntas pada mata pelajaran geografi materi Pelesterian Lingkungan Hidup.

Teknik pengumpulan data yang digunakan dalam penelitian adalah teknik observasi langsung, dimana peneliti dalam memperoleh data dengan melakukan pengamatan langsung ke lapangan dengan terfokus pada subjek/objek yang akan diteliti. Dengan kata lain, peneliti mengamati langsung guru dan siswa di kelas XI dalam proses pembelajaran di SMA Negeri 10 Singkawang dengan menggunakan pedoman observasi. Peneliti mengobservasi dari mulai perencanaan, pelaksanaan, dan evaluasi pembelajaran. Teknik komunikasi tidak langsung dalam penelitian adalah berupa pengisian angket oleh peserta didik kelas XI. Teknik komunikasi langsung yaitu melakukan wawancara setelah proses pembelajaran dan teknik studi dokumenter yaitu proses mendokumentasikan yang berkaitan penelitian berupa data nilai, foto-foto dalam proses pembelajaran. Sedangkan alat pengumpul data yang digunakan dalam pengumpulan data adalah APKG 1, APKG 2, angket, dan panduan wawancara yang akan digunakan dalam penelitian.

\section{HASIL DAN PEMBAHASAN}

Berdasarkan hasil APKG 1 yang dilakukan di kelas XI SMA Negeri 10 Singkawang, maka diperoleh data hasil observasi sebagai berikut. 
Tabel 1 Nilai APKG 1 Dan APKG 2

\begin{tabular}{ccc}
\hline Aspek yang Dinilai & Rata-Rata & Rata-Rata x Bobot \\
\hline APKG 1 & 3,65 & $3,65 \times 1=3,65$ \\
APKG 2 & 3,35 & $3,35 \times 3=10,05$ \\
\hline Jumlah & 13,7 \\
\hline Nilai $=\frac{13,7}{4}=3,425$ & &
\end{tabular}

Berdasarkan Tabel 1, maka hasil dari APKG 1 dan APKG 2 ialah 3,425. Kemudian peneliti menentukan kategori berdasarkan tabel tolok ukur berikut.

Tabel 2 Kategori Tolok Ukur

\begin{tabular}{cc}
\hline Persentase $(\boldsymbol{\%})$ & Kategori \\
\hline $3,25-4,00$ & Sangat Baik \\
$2,50-3,24$ & Baik \\
$1,75-2,49$ & Cukup \\
$<1,74$ & Kurang
\end{tabular}

Sumber: Permeneg PAN dan RB Nomor 16 Tahun 2010

Berdasarkan Tabel 2, maka penilaian terhadap guru geografi melalui APKG 1 dan APKG 2 terasuk dalam kategori "sangat baik" dengan skor rata-rata 3,425. Wawancara dilakukan untuk memperoleh data secara kualitatif tentang kompetensi profesional guru geografi di SMA Negeri 10 Singkawang. Pertanyaan dalam wawancara dibuat sesuai denga panduan wawancara yang telah dibuat sebelumnya.Wawancara dilakukan pada guru geografi pada tanggal 15 Juni 2018. Hasil dari wawancara tersebut dapat dijabarkan sebagai berikut: (1) Guru geografi dalam penguasaan landasan pendidikan menjelaskan tujuan pendidikan; (2) Guru geografi dalam penguasaan landasan pendidikan menjelaskan fungsi sekolah dalam masyarakat; (3) Guru geografi dalam penguasaan landasan pendidikan menjelaskan cara memotivasi siswa; (4) Guru gdalam penyusunan program pengajaran menjelaskan bahwa selalu menetapkan tujuan pembelajaran; (5) Guru geografi dalam penyusunan program pengajaran mengatakan bahwa mengembangkan bahan ajaran sesuai dengan tujuan pembelajaran; (6) Guru geografi dalam penyusunan program pengajaran mengatakan bahwa sebelum 
masuk kelas beliau telah memilih akan menggunakan strategi apa dan bagaimana pelaksanaannya; (7) Guru geografi dalam penyusunan program pengajaran mengatakan selalu menggunakan media pembelajaran dalam proses mengajar demi mendukung tercapainya pembelajaran yang efektif; (8) Guru juga menggunakan buku sumber Geografi SMA (ESIS); (9) Guru geografi dalam melaksanakan program pengajaran mengatakan bahwa menciptakan suasana belajar yang nyaman; (10) Guru geografi dalam melaksanakan program pengajaran mengatakan bahwa tidak pernah menyiasati lingkungan dan ruangan belajar; (11) Guru geografi dalam melaksanakan program pengajaran mengatakan bahwa menciptakan interaksi belajar mengajar; (12) Guru geografi dalam menguasai bahan pengajaran mengatakan bahwa agar siswa mampu menyerap semua materi yang disampaikan; (13) Guru geografi dalam menguasai bahan pengajaran mengatakan bahwa selalu membuka sesi tanya jawab; (14) Guru geografi dalam menilai hasil dan proses pembelajaran yang telah dilaksanakan mengatakan bahwa evaluasi terhadap siswa bukan hanya pada ujian semester; dan (15) Guru geografi dalam menilai hasil dan proses pembelajaran yang telah dilaksanakan mengatakan bahwa mengevaluasi proses belajar mengajar.

Deskripsi data angket diberikan kepada siswa yang menjadi sampel pada penelitian yaitu berjumlah 60 orang. Angket terdiri dari 20 item pertanyaan. Berikut hasil perhitungannya.

Tabel 3 Perhitungan Data Hasil Angket

\begin{tabular}{|c|c|c|c|c|}
\hline Indikator & Item & $\begin{array}{c}\text { Skor } \\
\text { Aktual }\end{array}$ & $\begin{array}{l}\text { Skor } \\
\text { Ideal }\end{array}$ & Persentase \\
\hline \multirow{8}{*}{$\begin{array}{c}\text { Penguasaan landasan pendidikan oleh } \\
\text { guru geografi }\end{array}$} & 1 & 178 & 240 & \\
\hline & 2 & 182 & 240 & \\
\hline & 3 & 134 & 240 & \\
\hline & 4 & 136 & 240 & \\
\hline & 5 & 172 & 240 & \\
\hline & 6 & 183 & 240 & \\
\hline & 7 & 183 & 240 & \\
\hline & 8 & 198 & 240 & \\
\hline Total & & 11.366 & 1.920 & $71,14 \%$ \\
\hline
\end{tabular}




\begin{tabular}{|c|c|c|c|c|}
\hline Indikator & Item & $\begin{array}{c}\text { Skor } \\
\text { Aktual }\end{array}$ & $\begin{array}{l}\text { Skor } \\
\text { Ideal }\end{array}$ & Persentase \\
\hline \multirow{5}{*}{$\begin{array}{l}\text { Penyusunan program pengajaran oleh } \\
\text { guru geografi }\end{array}$} & 9 & 198 & 240 & \\
\hline & 10 & 191 & 240 & \\
\hline & 11 & 198 & 240 & \\
\hline & 12 & 199 & 240 & \\
\hline & 13 & 198 & 240 & \\
\hline Total & & 984 & 1.200 & $82 \%$ \\
\hline \multirow{3}{*}{$\begin{array}{c}\text { Pelaksanaan program pengajaran oleh } \\
\text { guru geografi }\end{array}$} & 14 & 198 & 240 & \\
\hline & 15 & 113 & 240 & \\
\hline & 16 & 198 & 240 & \\
\hline Total & & 509 & 720 & $70,69 \%$ \\
\hline \multirow{2}{*}{$\begin{array}{l}\text { Penguasaan bahan pengajaran oleh guru } \\
\text { geografi }\end{array}$} & 17 & 202 & 240 & \\
\hline & 18 & 200 & 240 & \\
\hline Total & & 402 & 480 & $83,75 \%$ \\
\hline \multirow{2}{*}{$\begin{array}{l}\text { Menilai hasil dan proses belajar-mengajar } \\
\text { oleh guru geografi }\end{array}$} & 19 & 190 & 240 & \\
\hline & 20 & 174 & 240 & \\
\hline Total & & 364 & 480 & $\mathbf{7 5 , 8 3 \%}$ \\
\hline$\Sigma$ & & 3.625 & 4800 & $75,52 \%$ \\
\hline
\end{tabular}

Berdasarkan Tabel 3, maka dapat dilihat persentase dari tiap-tiap aspek kompetensi guru geografi dalam menyampaikan materi Lingkungan Hidup. Aspek pertama yaitu penguasaan landasan pendidikan dengan persentase $71,14 \%$ dengan kategori "baik". Aspek kedua yaitu penyusunan program pengajaran oleh guru geografi dengan persentase $82 \%$ dengan kategori "sangat baik". Aspek ketiga yaitu pelaksanaan program pengajaran dengan persentase 70,69\% dengan kategori "baik". Aspek keempat yaitu penguasaan bahan pengajaran oleh guru geografi dengan persentase $83,75 \%$ dengan kategori "sangat baik". Dan yang terkahir yaitu aspek menilai hasil dari proses belajar mengajar oleh guru geografi dengan persentase $75,83 \%$ dengan kategori "sangat baik".

Seorang pendidik yang baik tentunya memiliki standar tertentu yang dapat mengklasifikasikan dirinya menjadi guru yang berkompetensi ataupun tidak, 
sejalan dengan yang dikemukakan Tamyong (2015), yaitu orang yang terdidik dan terlatih dengan baik, serta memiliki pengalaman yang kaya dibidangnya.

Adapun alat yang digunakan untuk menilai kompetensi profesional guru dalam proses pembelajaran materi Lingkungan Hidup di kelas IX SMA Negeri 10 Singkawang adalah melalui angket, panduan wawancara, dan panduan observasi yang berupa APKG (Alat Penilaian Kompetensi Guru) 1 dan 2. Sedangkan indikator penilaiannya, sesuai dengan kompetensi profesional secara spesifik (Usman, 2015), tentang kinerja guru yang meliputi 5 hal, yaitu penguasaan landasan pendidikan, penyusunan program pengajaran, pelaksanaan program pengajaran, penguasaan bahan pengajaran, dan menilai hasil dan proses pembelajaran. Hal tersebut yang dijadikan acuan oleh peneliti untuk bisa menganalisis kemamuan profesional guru geografi di kelas XI SMA Negeri 10 Singkawang. Peneliti mengumpulkan data secara langsung dari siswa guna mendapatkan data yang akurat dan valid. Peneliti merancang angket sebanyak 20 pertanyaan untuk mejawab yang mencakup kelima aspek dalam APKG. Kemudian, sampel penelitian menjawab angket tersebut.

Data yang diperoleh kemudian ditransformasikan ke dalam bentuk persentase. Aspek yang pertama mendapat persentase sebesar $71,14 \%$ dengan kategori "baik". Aspek penguasaan landasan pendidikan sudah cukup dilaksanakan oleh guru geografi. Terbukti dengan beliau memiliki kompetensi kepribadian sesuai dengan yang tercantum dalam penjelasan peraturan pemerintahan No. 19 tahun 2005 tentang standar nasional pendidikan dimana selalu menanamkan nilai-nilai atau pendidikan karakter pada siswanya. Contohnya guru selalu menekankan nilai moral seperti kejujuran, kerja keras, kerjasama dan nilai disiplin dalam mengajar. Hal tersebut tentu sangat baik demi membentuk karakter siswa sesuai dengan landasan nasional pendidikan.

Aspek selanjutnya yaitu penyusunan program pengajaran. Aspek tersebut mendapatkan persentase sebesar 82\% dengan kategori "sangat baik". Persentase yang tinggi tersebut bisa dicapai karena guru dinilai sangat konsisten dalam pembelajaran. Guru selalu menjelaskan tujuan pembelajaran di awal kelas. Hal tersebut membuat siswa lebih fokus dan termotivasi untuk belajar karena dari 
awal siswa sudah mengetahui tujuan dari pembelajaran. Guru juga merancang strategi yang akan digunakan dengan sangat baik, misalnya ketika akan mengggunakan strategi diskusi, guru sudah menyiapkan tema apa saja yang akan dibahas oleh masing-masing kelompok. Penyusunan program pengajaran yang baik bisa sangat memengaruhi berjalannya pengajaran tersebut. Hal tersebut yang diharuskan dalam kompetensi profesional yang tercantum dalam penjelasan peraturan pemerintahan No. 19 tahun 2005 tentang standar nasional pendidikan.

Aspek ketiga yaitu pelaksanaan program pengajaran dengan persentase 70,69\% dengan kategori "baik". Pelaksanaan program pengajaran meliputi penggunaan media, penyampaian materi secara lisan, juga manajemen kelas yang baik. Guru geografi sebagai objek penelitian dinilai bisa secara baik dalam melaksanakan program pengajaran. Guru menyiapkan media dan menggunakannya secara efektif di kelas. Penyampaian materi juga dengan menggunakan bahasa dan tutur kata yang mudah dimengerti siswa menjadikan siswa lebih termotivasi dan betah untuk mendengarkan penjelasan guru. Penggunaan strategi yang variatif juga menjadikan suasana kelas tidak monoton sehingga semangat siswa menjadi terjaga untuk mengikuti pelajaran geografi.

Aspek keempat yaitu penguasaan bahan pengajaran oleh guru geografi dengan persentase $83,75 \%$ dengan kategori "sangat baik". Penguasaan bahan atau materi pengajaran sangat penting bagi seorang guru, karena guru adalah sebagai acuan atau pedoman dalam mencari informasi bagi siswa. Aspek tersebut mendapat nilai persentase yang baik karena guru geografi selalu berusaha memberikan informasi selengkap-lengkapnya kepda siswa. Guru juga selalu berusaha berinteraksi dengan siswa demi mengetahui kesulitan yang dialami siswa dalam memahami materi yang disampaikan.

Aspek terakhir yaitu aspek penilaian atau evaluasi. Aspek tersebut mendapat persentae sebesar 75,83\% dengan kategori "sangat baik". Menurut siswa, guru sudah memberikan evaluasi yang sangat baik untuk siswa. Sangat baik adalah bersifat objektif dan sesuai dengan pembelajaran yang diberikan. Guru juga sering memberikan tugas maupun ulangan harian agar siswa bisa menjadi lebih semangat untuk mendapatkan nilai yang baik di setiap tugas maupun ulangan. 
Berdasarkan hasil uraian analisis tersebut, guru geografi kelas XI SMA Negeri 10 Singkawang mendapatkan penilaian yang sangat baik dari kelima aspek kompetensi guru dengan total persentase $75,52 \%$. Hal tersebut tentu menjadi harapan agar siswa bisa mencapai prestasi yang baik khususnya pada mata pelajaran Geografi. Tingkat profesionalitas yang tinggi sangat diperlukan bagi seorang guru sebagai pendidik bagi siswa yang mana akan menjadi penentu masa depan suatu bangsa. Oleh karenanya, semua guru haruslah terus berupaya untuk meningkatkan kemampuan dan kompetensi guna mencapai tujuan awal dari pendidikan yaitu menciptakan generasi bangsa yang bermartabat, berkarakter, dan berdaya saing sesuai tuntutan visi undang-undang No. 14, 2005.

\section{SIMPULAN}

Berdasarkan hasil analisis data yang telah dilakukan, maka dapat ditarik kesimpulan bahwa kompetensi profesional guru geografi dalam proses pembelajaran materi Lingkungan Hidup kelas XI SMA Negeri 10 Singkawang dikategorikan "sangat baik" dengan peroleh nilai dari hasil penilaian APKG 1 dan 2. Sedangkan dari hasil angket dengan kategori "sangat baik". Penyusunan program pengajaran guru geografi dalam proses pembelajaran materi Lingkungan Hidup di kelas XI SMA Negeri 10 Singkawang dengan kategori "sangat baik". Pelaksanaan program pengajaran guru geografi dalam proses pembelajaran materi Lingkungan Hidup di kelas XI SMA Negeri 10 Singkawang dengan kategori "baik". Peguasaan bahan pengajaran guru geografi dalam proses pembelajaran materi Lingkungan Hidup di kelas XI SMA Negeri 10 Singkawang dengan kategori " sangat baik". Penilaian hasil proses pembelajaran guru geografi dalam proses pembelajaran materi Lingkungan Hidup di kelas XI SMA Negeri 10 Singkawang dengan kategori "sangat baik".

\section{DAFTAR PUSTAKA}

Aminah, S. 2008. Hubungan Persepsi Siswa tentang Kemampuan Mengajar Guru Kimia dan Motivasi Belajar terhadap Prestasi Belajar Kimia Siswa. Tesis Pendidikan Kimia Universitas Islam Negeri Sunan Kalijaga. Jawa Tengah.

Andrianto, H. 2008. Pemrograman Mikrokontroler AVR ATmega8535. Informatika. Bandung: Erlangga. 
Arikunto, S. 2016. Statistika Penelitian. Jakarta: Rienika Cipta.

Arikunto, S. 2015. Manajemen Penelitian. Jakarta: Rineka Cipta.

Febriani, D. M. 2011. Hubungan antara Persepsi terhadap Word Of Mouth (WOM) dengan Intensi Makan Vegetarian pada Mahasiswa Fakultas Psikologi Universitas Diponorogo Semarang. Jurnal Psikologi Undip, 10(1): 172-183.

Ginting, S. H. 2008. Filsafat Ilmu dan Metode Riset. Medan: Usu Press.

Rosadi, I. 2001. Keunggulan Kompetitif Berkelanjutan melalui Capabilities-Based Competition: Memikirkan Kembali tentang Persaingan Berbasis Kemampuan. Jurnal BENEFIT, 5(1): 35-48.

Setriani, L. 2017. Persepsi Mahasiswa tentang Keterampilan Variasi Mengajar Dosen. Sosial Horizon: Jurnal Pendidikan Sosial: 238-246.

Sugiyono. 2013. Metode Penelitian Pendidikan (Pendekatan Kuantitatif, Kualitatif, dan $R \& D)$. Bandung: Alfabeta.

Sukmadinata. 2014. Metode Penelitian. Yogyakarta: Rienika Cipta.

Sukmadinata, N. S. 2004. Landasan Psikologi Proses Pendidikan. Bandung: PT. Remaja Rosdakarya.

Sunaryo. 2004. Psikologi Untuk Keperawatan. Jakarta: EGC.

Tamyong, A. T. 2015. Profesional Guru. Jakarta: Raja Grafindo Persada.

Undang-Undang. (1989). Sistem Pendidikan Indonesia Nomor 2. Jakarta: Kepmen.

Undang-Undang. 2015. Sistem Pendidikan Nasional Nomor 20 Tahun 2003. Jakarta: Depdiknas.

Undang-Undang RI Pasal 10 Ayat 1. 2015. Jakarta: Seketariat Jendral Departemen Pendidikan Nasional.

Usman, U. 2015. Profesi Keguruan dan Pendidikan. Bandung : Citra Umbara.

Wardani, I. K. 2009. Mengurangi Persepsi Negatif Siswa tentang Konselor Sekolah dengan Strategi Pengubahan Pola Pikir C. Psikologi Pendidikan dan Bimbingan (Prodi BK FIP Unesa), 10(2): 234. 